\title{
A Case of Transoral Endoscopic Excision of Recurred Synovial Sarcoma in Pyriform Sinus
}

\author{
Myung Jin Ban ${ }^{1}$, Jae Hong Park, Min Ho Noh ${ }^{1}$, and Ji Hye Lee ${ }^{2}$ \\ ${ }^{1}$ Departments of Otolaryngology-Head and Neck Surgery, ${ }^{2}$ Pathology, Soonchunhyang University College of Medicine, Cheonan, Korea
}

\section{이상와에 국소 재발한 활막육종의 경구강 내시경 하 절제술 1예}

반명진 $^{1} \cdot$ 박재홍 $^{1} \cdot$ 노민호 $^{1} \cdot$ 이지혜 ${ }^{2}$

순천향대학교 의과대학 천안병원 이비인후과학교실, ${ }^{1}$ 병리학교실 ${ }^{2}$

\author{
Received May 29, 2015 \\ Revised September 2, 2015 \\ Accepted September 4, 2015 \\ Address for correspondence \\ Jae Hong Park, MD \\ Department of Otolaryngology- \\ Head and Neck Surgery, \\ Soonchunhyang University \\ College of Medicine, \\ 31 Suncheonhyang 6-gil, \\ Dongnam-gu, Cheonan 31151, Korea \\ Tel $+82-41-570-2265$ \\ Fax $+82-41-579-9022$ \\ E-mail entparkong@hanmail.net
}

Synovial sarcoma in head and neck is an extremely rare cancer. Symptoms may occur depending on the location of tumor. Synovial sarcoma is divided into two main phenotypes-biphasic and monophasic. Surgical excision including optimal resection margin is generally recommended as a standard treatment of synovial sarcoma, if the tumor is resectable. Standard adjuvant therapy of synovial sarcoma has not been established yet. Recently, we have experienced a case of recurrent synovial sarcoma in pyriform sinus without regional or distant metastasis after initial resection of tumor. We successfully performed endoscopic excision of recurred tumor and obtained clear resection margin. We followed up the patient without any adjuvant therapy for 2 years. We report this rare case with literature review.

Korean J Otorhinolaryngol-Head Neck Surg 2016;59(5):383-7

Key Words Endoscopy · Hypopharyngeal neoplasm · Synovial sarcoma.
서 론

육종(sarcoma)은 두경부에 발생하는 악성 종양 중 $1 \%$ 를 차 지하는 드문 암이며, 그중 활막육종(synovial sarcoma)은 두 경부 육종의 $10 \%$ 를 차지하는 매우 드문 암이다. ${ }^{1)}$ 두경부 육 종의 발생 위치로는 하인두(hypopharynx)가 호발 부위로, 위 치에 따라 다양한 증상이 일어날 수 있다.2 활막육종의 치료 는 조기에 충분한 변연을 확보한 절제술이 가장 중요하며 보 조 치료요법(adjuvant treatment)에 대해서는 아직 정립된 바 없다. 저자들은 후두미세수술을 이용한 절제술 시행 후 3년 만에 경부 또는 원격 전이(regional or distant metastasis) 없 이 국소 재발(local recurrence)된 이상성 활막육종을 경구강 내시경을 통해 안전한 절제연을 확보한 절제가 가능하였기에 문헌 고찰과 함께 증례를 보고하는 바이다.
증 례

52 세 남자 환자가 1 일 전부터 발생한 간헐적인 호흡곤란과 후두압박감을 주소로 내원하였다. 내원하여 시행한 후두내시 경 상 좌측 하인두 후벽에서 기원하여 후두 전체를 덮고 있는 비교적 경계가 명확한 약 $4 \mathrm{~cm}$ 크기의 구형 종괴가 발견되었 고(Fig. 1), 애성은 없었으나 종물하방의 성대의 움직임은 확 인할 수 없었다. 과거력 상 내원 3년 전에도 본원에서 좌측 하 인두의 약 $3 \mathrm{~cm}$ 크기의 종괴를 발견하여 전신마취 하에 기관 절개술 없이 후두미세수술로 절제하였고, 술 후 조직검사상 절제연에 종양침윤소견을 보인 이상성 활막육종(biphasic type synovial sarcoma with involvement of resection margin)으 로 보고된 바 있어 당시 충분한 변연 확보를 위해 재수술, 혹 은 보조방사선치료를 권유하였으나 환자의 거부로 추적관찰 은 할 수 없었다.

경부 전산화단층촬영 $(\mathrm{CT})$ 소견 상 후두덮개와 좌측 하인두 


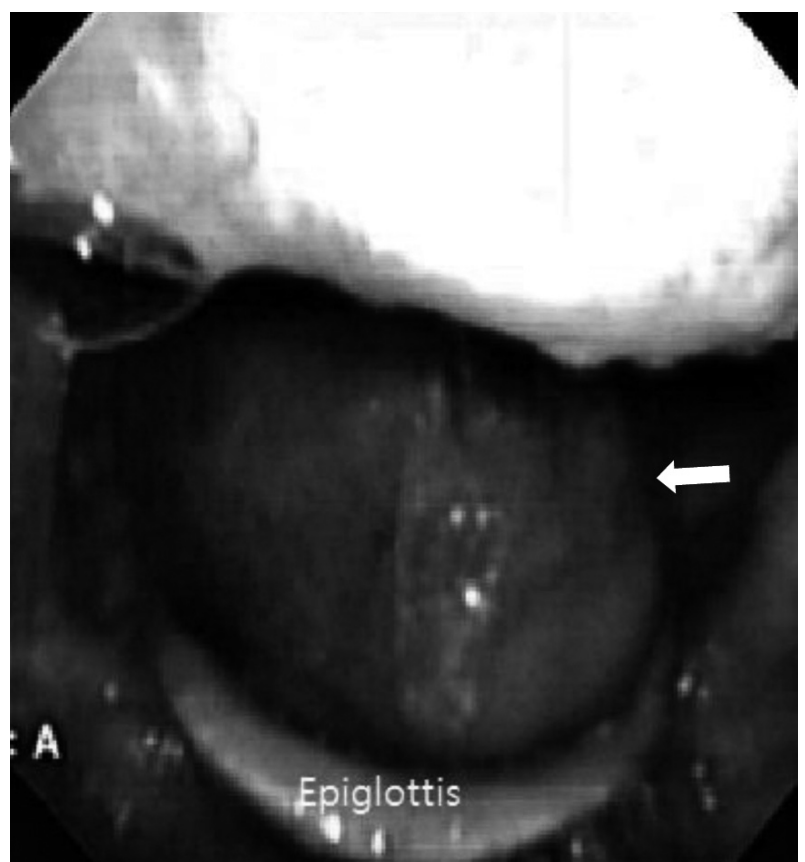

Fig. 1. Preoperative laryngoscopic view. The huge, well capsulated mass lying over the larynx is noted at the hypopharynx (white arrow). 후벽(posterior wall of hypopharynx) 사이에 $4 \times 3 \mathrm{~cm}$ 크기의 경계가 명확한 구형의 종물이 후두상부에 위치해 있었으며 (Fig. 2A and B) 3년 전 전산화단층촬영(CT)과 비교 시 종괴 크기의 차이는 있지만 위치는 유사하였다 (Fig. 2C). 후두상부 에 위치한 종물의 간헐적인 후두내로의 폐색으로 인해 극심 한 호흡곤란을 반복적으로 호소하여 국소마취 하에 응급기관 절개술을 시행하였고 기관절개술 후 전신마취로 전환하여 McIvor mouth gag(Codman \& Shurtleff, Inc., Raynham, $\mathrm{MA}, \mathrm{USA})$ 와 $4 \mathrm{~mm}, 30^{\circ}$ 내시경을 이용하여 좌측 이상와 입 구 하인두를 노출시킨 후 종괴의 하인두 후벽 기원부위와 범 위를 확인 후 절개생검을 시행하였고 술 후 조직검사상 이상 성 활막육종의 재발을 확인하였다. 경부 진찰 상 종양이나 림 프절 비대는 관찰되지 않았고 전신 양전자단층촬영(positron emission tomography-computed tomography)에서 하인두 종괴 외의 전이소견은 보이지 않았다. 경부 자기공명검사 (MRI)에서는 T2 강조영상에서 증가된 신호강도를 보이며, 조 영 증강 및 부분적인 석회화를 보이고 있었고, 주변부위로 침 범 소견은 보이지 않았다(Fig. 3). 흉부 방사선 촬영, 위내시경
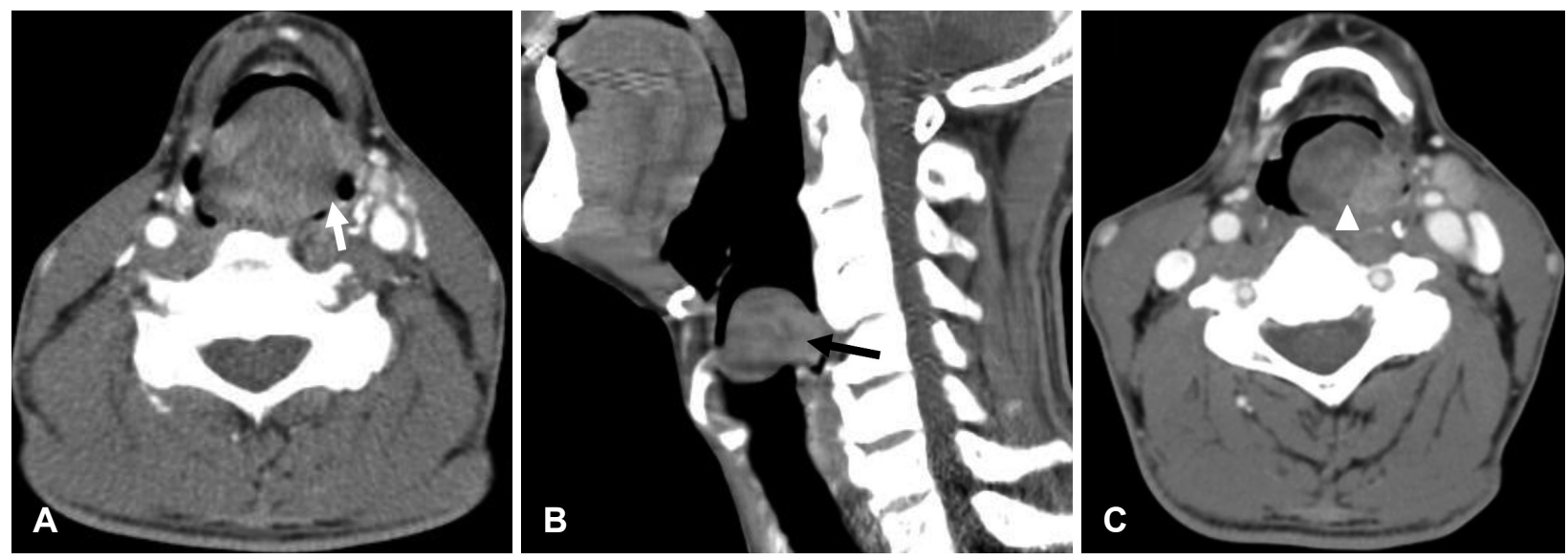

Fig. 2. Axial view of CT scan shows well-demarcated mass from posterolateral wall of left pyriform sinus (white arrow) (A). Sagittal view of CT scan shows huge mass form hypopharyngeal wall lying over laryngeal inlet (black arrow) (B). Axial view of CT scan of 3 years ago shows $3 \mathrm{~cm}$ sized well-demarcated mass at same place (white arrowhead) (C).
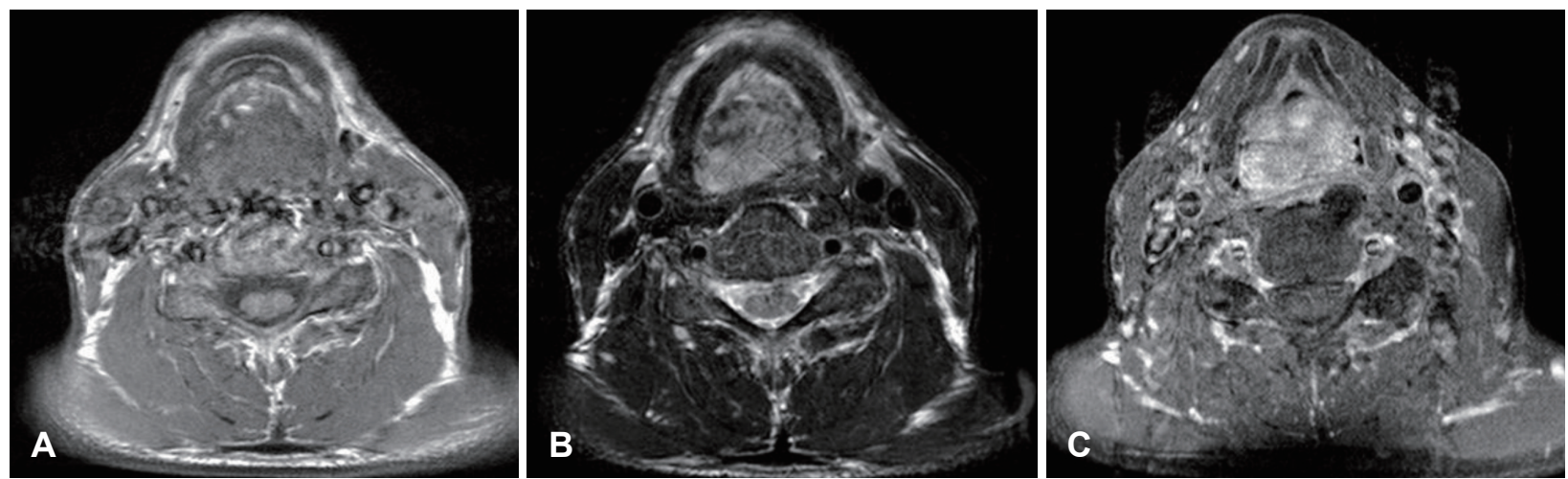

Fig. 3. Axial view of T1-weigted MR image shows huge mass with heterogenous intermediate signal intensity at hypopharynx (A) and the mass shows high signal intensity at T2-weighted MR image (B). Gadolinium-enhanced T1-weighted image show well-enhancing mass from left posterolateral wall of hypopharynx (C). 
검사, 혈액 및 소변 검사에서도 특이 소견은 없었다. 국소 림프 절 침윤이나 원격 전이가 없음을 확인한 후 재발된 종양의 완 전절제를 위해 경구강 내시경절제술을 다시 계획하였고, 종 양의 제거를 위한 하인두 노출이 충분하지 않거나 안전한 절 제연을 얻기 힘든 경우 경부절개를 통해 외측인두절개 접근 법(lateral pharyngotomy approach)을 이용하여 수술을 진 행하기로 하였다. 경구강 내시경수술을 위해 McIvor mouth $\mathrm{gag}$ 와 $4 \mathrm{~mm}, 30^{\circ}$ 내시경을 이용하여 좌측 이상와 입구를 노 출하였고, 이상와 후벽의 종양기원부위의 범위를 확인할 수 있었다. 하인두와 후두를 덮고 있는 거대한 종양을 Yankauer suction tip(Codman \& Shurtleff Inc.)을 이용하여 하내측 (inferomedial direction)으로 밀어 종양의 하인두후벽과의
부착부위를 확인 및 노출하였고, $5 \mathrm{~mm}$ 이상의 안전한 절제 연을 고안한 후 전기소작기를 이용하여 종양부착부위 상부 부터 절제하였다(Fig. 4). 절제 후 냉동절편검사를 통해 절제 연 변연부와 심부에서 각각 종양침습이 없음을 확인한 후 수 술을 종료하였다. 절제된 종괴의 육안검사 상 종괴는 $4 \times 3.5$ $\mathrm{cm}$ 크기였고 경계가 불분명하였다. 종괴의 단면에서 부분적 으로 출혈과 여러 개의 소낭이 관찰되었다(Fig. 5A). 현미경 소견상 종괴는 경계가 불분명한 다결절성 성장양상을 보였고 (Fig. 5B), 원주상피세포와 그 주위를 감싸는 방추형세포로 구성되어 있었다(Fig. 5C). 면역 조직 화학 염색에서 상피 세 포(epithelial cell)에서는 cytokeratin pan antibody monoclonal (Pan-CK), CD99, epithelial membrane antigen(EMA)에서
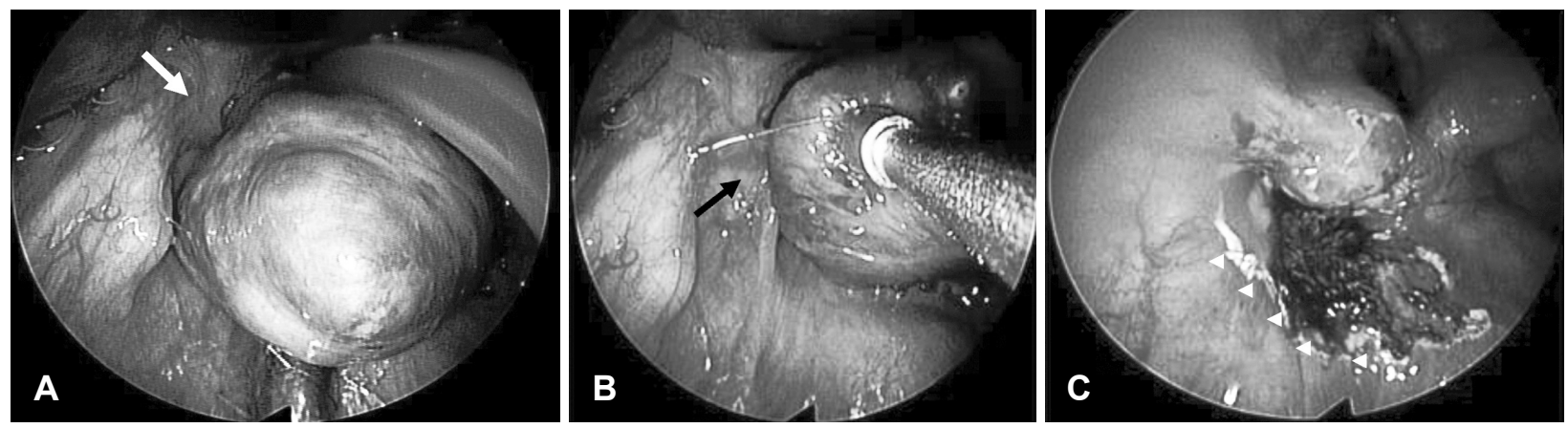

Fig. 4. Operative findings. Transoral endoscopic view shows well capsulated huge mass attatched to the left posterolateral wall of hypopharynx (white arrow) (A). The mass is retracted inferomedially with suction tip and stalk of mass attatched to the hypopharyngeal wall is noted (black arrow) (B). Mass was removed with clear margin followed by additional excision along the resection margin and base of surgical defect to get optimal surgical margin arrowhead (C).
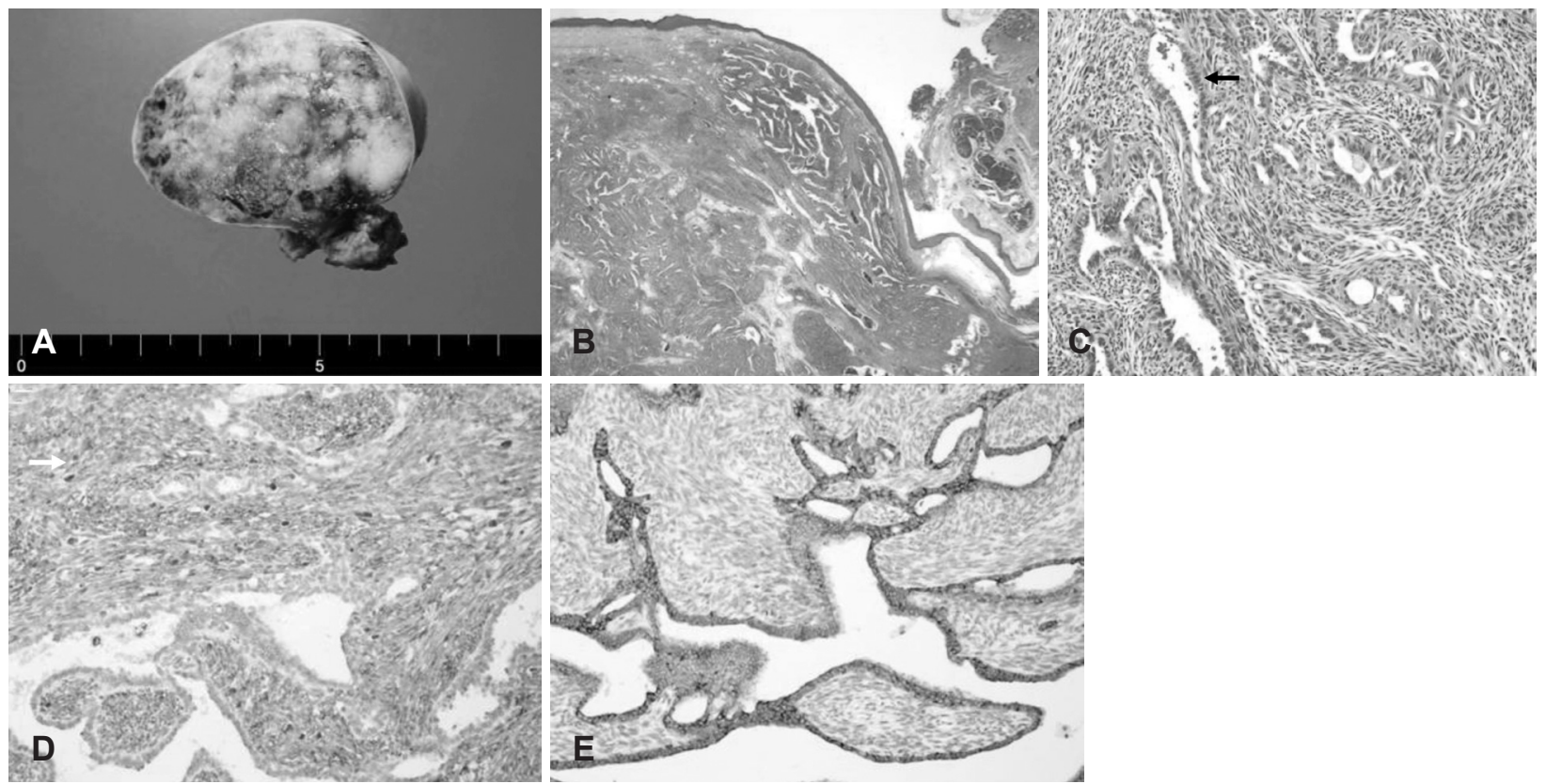

Fig. 5. Glossly, there is a poorly defined soft mass in the submucosa. The cut-surface of mass shows pale gray-tan appearance with focal hemorrhage and small cyst formation (A). In the low power view, the tumor shows poorly circumscribed, and multinodular growing pattern $(\times 12.5, \mathrm{H} \& \mathrm{E})(\mathrm{B})$. The tumor consists of columnar epithelial cells (black arrow) surrounded by spindle cells (white arrow) $(\times$ $200, H \& E)(C)$. In the immunohistochemical staining, the surrounding spindle cells are reactive for vimentin $(\times 200)(D)$. The epithelial cells are positive for pancytokeratin $(\times 200)(E)$. 
양성, vimentin에서 음성을 보였으며, 방추형 세포(spindle cell) 에서는 vimentin, EMA, CD99에서 positive, Pan-CK에서 음 성소견 보였다(Fig. 5D and E). Ki-67은 약 5 10\%에서 반응 을 보여 이상성 활막육종에 합당한 소견이었다. 수술 후 1 일째 기관튜브를 발관 후 구강을 통한 연식섭취를 시작하였고 수 술 후 5일째 퇴원하였다. 조직검사 상 심부 안전 절제연이 종괴 로부터 $2 \mathrm{~mm}$ 로 근접한 소견을 보여 방사선치료를 계획하였 으나, 환자의 거부로 시행하지 못하고 경과관찰 중이다. 술 후 2 년째 후두경 검사 및 전산화단층촬영 상 재발 소견은 없다.

\section{고 찰}

두경부의 활막육종은 매우 드물어 전체 두경부 악성 종양 의 $0.1 \%$ 를 차지하며, 국내에도 12 예 정도만 보고되었다. ${ }^{1)}$ 예후 는 비교적 양호하여 5년 생존율은 40 50\%로 보고되고 있 다. ${ }^{3)}$ 대부분 본 증례와 같이 무증상의 종괴로 우연히 발견되 지만 활막육종의 위치에 따라 다양한 증상을 나타낼 수 있다. 전산화단층촬영에서는 석회화를 보이는 경우가 $50 \%$ 이상이 며, 연부조직 침범 여부 및 범위를 알기 위해 자기공명 영상이 필요하다. ${ }^{4}$

조직학적으로 이상성(biphasic type)과 단상성(monophasic type)의 2 가지 아형(phenotype)으로 나뉜다. 단상성은 방추형 세포(spindle cells)로만 구성되어 있고 이상성은 방추형 세포 와 상피양 세포(epithelial cells)가 함께 구성되어 있다. 이 중 단상성이 더 흔하며, 두 분류 간 생존율의 차이는 없다. ${ }^{5)}$ 면역 염색에서 상피양 세포에서는 EMA, bcl-2, cytokeratin에서는 주로 양성소견을 보이며, 방추형 세포에서는 간엽 표지자인 vimentin과 상피양 세표 표지자인 bcl-2이 양성소견을 나타 내는 경우가 많다. 본 증례에서 상피양세포에서 EMA에 양성 소견, 방추형 세포에서 vimentin에 양성소견을 보였고 $\mathrm{Ki}-67$ proliferation index에서 약 5 10\%에서 반응을 보여 이상성 양상의 활막육종에 합당한 소견이었다. 중합효소 연쇄 반응 (polymerase chain reaction) 혹은 면역표현형검사(immunophenotyping technique)를 이용하면 세포유전학적 전위(X;18) (p11;q11)가 활막육종에서 $90 \%$ 이상 발견되나, ${ }^{6}$ 본 증례에서 는 시행하지 못하였다.

활막육종의 치료의 핵심은 충분한 절제연을 확보한 수술적 제거이며 국소 재발률을 낮추는 데 있어서도 충분한 절제연이 가장 중요하다.,5) 이전까지 하인두의 활막육종에서 충분한 절 제연을 얻기 위해 대부분 경부절개를 통한 외측인두절개 접근 법을 사용하였으며, 시험적으로 transoral robotic resection 을 이용한 절제가 보고되었다. ${ }^{7)}$ 또한 내시경적 절제를 시행하 였으나, 충분한 절제연을 확보하지 못해 결국 경부절개를 통
해 제거를 시행한 증례 및 내시경과 $\mathrm{CO}_{2}$ laser를 통해 제거 한 증례도 보고되었다. ${ }^{8)}$ 본 증례에서는 주변조직으로 침범이 보이지 않는 하인두 활막육종에서 내시경 하 절제술로 절제 연을 확보할 수 있었다. 수술 전 림프절 전이의 근거가 없다면 경부 절제술은 불필요하며, 본 증례에서도 시행하지 않았다. ${ }^{9)}$

두경부의 활막육종은 매우 드문 질환이기에 수술 후 보조 치료(adjuvant therapy)의 적응증, 종류, 방법 및 그 효율성에 대하여는 아직 확실히 정립되지 않았지만 충분한 절제연이 확 보되지 않을 경우 또는 절제연 밖의 종양의 침습이 예상되는 경우 수술 후 보조 방사선 치료는 국소 재발률 감소에 도움이 된다고 보고되어 있다. ${ }^{10)}$ 술 후 보조방사선치료의 표준 용량 역시 정립되어 있지 않으나, 65 70 Gy의 용량으로 시행함이 보편적이다. ${ }^{11)}$ 본 증례의 경우 하인두 종양에 대한 첫 절제술 후 절제연의 양성소견을 보인 이상성 활막육종으로 보고되어 재수술 또는 보조방사선치료를 권유하였으나, 환자의 거부로 모두 시행하지 못한 채 추적관찰이 종료되었고, 이로 인해 국 소 재발을 조기에 발견하지 못하여 재발된 종괴가 $4 \mathrm{~cm}$ 까지 자라게 된 점은 아쉬운 점이라 할 수 있다. 기타 항암치료의 역할에 대해서는 아직 논란이 되고 있으나 Santoro 등리의 연 구에 따르면 ifosfamide와 doxorubicin을 이용한 항암치료를 시행한 군에서 무병생존율(disease-free survival) 및 전체생 존률(overall survival) 모두 상승됨이 보고된 바 있다. ${ }^{13)}$

불량한 예후를 나타내는 인자로는 고령, 종물의 크기 $(>5 \mathrm{~cm})$, $>10$ mitoses/high powered field, 낮은 조직학적 분화도, 골 침범 및 절제연 양성 등이 있다. ${ }^{2,5)}$ 종물의 크기는 보통 4 5 $\mathrm{cm}$ 를 기준으로 유의하게 생존율의 차이가 나며 ${ }^{2)}$ 본 증례에서 는 나이는 52 세이나, 크기가 $5 \mathrm{~cm}$ 미만이고, 전이가 없었던 점 으로 보아 예후는 비교적 좋을 것으로 예상되었다. 사망률 (mortality)은 대부분 혈행성 전이에 의한 전이 부하(metastatic burden)에 의하며, 특히 두경부의 활막육종은 사지의 활막육종보다 전이의 확률이 높다고 보고되어 있다. ${ }^{14)}$ 국소 림 프절 전이는 $20 \%$ 까지 보고되고 있으며, 충분한 절제연을 확 보하지 못하여 절제연 내 종괴 양성일 경우 2 년 내 국소 재발 률은 60 90\%로 보고되고 있다. ${ }^{15)}$ 본 증례에서는 수술 전 병 기설정검사에서 원격전이 및 경부 림프절 전이 소견을 보이지 않아 경구강 내시경절제술을 시행할 수 있었으나, 수술 시 심 부경계를 충분히 확보하지 못한 점 $(2 \mathrm{~mm})$ 과 그로 인해 술 후 보조적인 방사선 치료를 계획하였음에도 환자의 거부로 인해 시행하지 못 하고 추적관찰 중인 점은 아쉬운 부분이라 할 수 있다.

\section{REFERENCES}

1) Sturgis EM, Potter BO. Sarcomas of the head and neck region. Curr Opin Oncol 2003;15(3):239-52. 
2) Bukachevsky RP, Pincus RL, Shechtman FG, Sarti E, Chodosh P. Synovial sarcoma of the head and neck. Head Neck 1992;14(1):44-8.

3) Roth JA, Enzinger FM, Tannenbaum M. Synovial sarcoma of the neck: a followup study of 24 cases. Cancer 1975;35(4):1243-53.

4) Mahajan H, Lorigan JG, Shirkhoda A. Synovial sarcoma: MR imaging. Magn Reson Imaging 1989;7(2):211-6.

5) Harb WJ, Luna MA, Patel SR, Ballo MT, Roberts DB, Sturgis EM. Survival in patients with synovial sarcoma of the head and neck: association with tumor location, size, and extension. Head Neck 2007; 29(8):731-40.

6) Cihak RA, Lydiatt WM, Lydiatt DD, Bridge JA. Synovial sarcoma of the head and neck: chromosomal translation $(\mathrm{X} ; 18)$ as a diagnostic aid. Head Neck 1997;19(6):549-53.

7) Kokot N, Mazhar K, O’Dell K, Huang N, Lin A, Sinha UK. Transoral robotic resection of oropharyngeal synovial sarcoma in a pediatric patient. Int J Pediatr Otorhinolaryngol 2013;77(6):1042-4.

8) Fonseca AS, Azevedo AC, Magalhães FM, Andrade NA. Synovial sarcoma in head and neck: a case report. Int Arch Otorhinolaryngol 2014;18(1):87-9.

9) Shin DJ, Kim SH, Baek SK, Jung KY. A case of synovial sarcoma arising in the supraglottis. Korean J Otolaryngol-Head Neck Surg
2005;48(4):526-8.

10) O'Sullivan PJ, Harris AC, Munk PL. Radiological features of synovial cell sarcoma. Br J Radiol 2008;81(964):346-56.

11) Lukšić I, Virag M, Manojlović S, Obradović B, Macan D, Stepan J. Primary synovial sarcoma of the parotid gland in 15-year-old boy. J Craniomaxillofac Surg 2011;39(6):445-8.

12) Santoro A, Tursz T, Mouridsen H, Verweij J, Steward W, Somers R, et al. Doxorubicin versus CYVADIC versus doxorubicin plus ifosfamide in first-line treatment of advanced soft tissue sarcomas: a randomized study of the European Organization for Research and Treatment of Cancer Soft Tissue and Bone Sarcoma Group. J Clin Oncol 1995;13(7):1537-45.

13) Dei Tos AP, Dal Cin P, Sciot R, Furlanetto A, Da Mosto MC, Giannini C, et al. Synovial sarcoma of the larynx and hypopharynx. Ann Otol Rhinol Laryngol 1998;107(12):1080-5.

14) Mullen JR, Zagars GK. Synovial sarcoma outcome following conservation surgery and radiotherapy. Radiother Oncol 1994;33(1): 23-30.

15) Lee GH, Lee BC, Kwon YJ, Jung YW. Two cases of synovial sarcoma arising in the anterior neck. Korean J Otolaryngol-Head Neck Surg 2006;49(9):952-5. 